Obstacles or motors of Europeanization? German media and the transnationalization of public debate

by R. Koopmans \& B. Pfetsch

To cite this article:

Koopmans, R. \& B. Pfetsch. (2006). Obstacles or motors of Europeanization? German media and the transnationalization of public debate. Communications, 31, 115-138

Published in:

Communications (ink to article)

Copyright:

The Authors, 2006

DOI:

$\underline{10.1515 / C O M M U N .2006 .009}$ 


\title{
Obstacles or motors of Europeanization? German media and the transnationalization of public debate
}

\author{
RUUD KOOPMANS and BARBARA PFETSCH
}

\section{Abstract}

This article aims to contribute to the discussion on the Europeanization of public spheres. It is the starting point for an investigation into the role of the media in transnational debate in Germany. The study aims to determine whether the media function as either a motor of or an obstacle to Europeanization of national public debate, compared to other actors. Drawing on empirical data from the project "The transformation of political mobilisation and communication in European public spheres" (Europub.com), we analyze the communications through which political actors, civil society actors, and the media in Germany make public demands on European issues. Sources on which this investigation was built were the news and editorial section of two national quality newspapers (center-left, center-right), one tabloid and one regional newspaper in the period between 2000 and 2002. The findings show that the demands made by the media are generally more European in scope than those made by other political actors. Regarding the evaluation of EU integration and the frames that are advocated, the German press and the political elite are rather convergent.

Keywords: public sphere, Europe, public debate, newspaper, Germany

\section{Introduction}

In the discussion on the democratic deficit of the European Union, it is widely acknowledged that to overcome a lack of legitimacy and popular involvement in top-down political and economic integration, a Europeanization of public communication is needed. This function of public communication in the European democratization process has triggered a vivid debate on the nature of a European public sphere and the conditions of its emergence (Neidhardt, Koopmans, and Pfetsch, 2000). Scholars agree that the mass media are the prime forum for the public representation of a European public sphere. The emergence of a politically 
relevant European media system, however, seems unrealistic. Most studies, for various reasons - such as language, cultural heterogenety, and the national make up of media systems - refer to European sphere in terms of a Europeanization of national public spheres. The ambitions of projects that do aim to identify a potentially emerging European public sphere focus on the mass media and try to establish the prominence of European issues and actors in media coverage over time (Gerhards, 2000; Eilders and Voltmer, 2004), or across countries (Peter and de Vreese, 2003; Kevin, 2003; Eder and Trenz, 2000).

The empirical studies on the visibility of European issues and actors maintain that the Europeanization of the public sphere is rather low (Gerhards, 2000). Interestingly enough, studies of media coverage explicitly or implicitly - share the assumption that the Europeanization of national public spheres is in the interest of the majority of political and economic elites in EU member states. The media are considered an obstacle to Europeanized political communication. It is argued that the logic of the media and in particular the rationales of newsmaking - for instance, the professional news values as selection criteria of messages, the goal of attracting large national audiences by personalized, conflictual, and event-driven coverage and their disinterest in administrative, policy driven information - result in a lack of interest in European issues and actors, and eventually keep public political debate within the boundaries of the nation state (Gerhards, 1992, 1993). Thus, the media are held responsible for the resilience of largely nationally focused public spheres.

In this study, we aim to determine whether the media are rightly or wrongly accused of being an obstacle to the Europeanization of national public spheres. Our empirical basis is an analysis of the structure of public claims made on several issues in Germany between 2000 and 2002. This analysis allows us to compare claims made by the media themselves to those made by other collective actors, both state and party elites, and actors from within civil society. The article is divided in three sections. In the first section, the role of the media in the debate on the Europeanization of public spheres is briefly discussed and a review of the findings of current research is given. A critical discussion of these studies introduces the approach used in the present study. We maintain that Europeanization should be studied with reference to the structures and scopes of public debate in specific policy areas. The empirical analysis draws on data from the project "The transformation of political mobilisation and communication in European public spheres" (Europub. com). Communication is analyzed through which political actors and media actors make public demands on selected issues. Claims made by collective actors are compared that appeared in the news sections of a sample of 
German newspapers. They are compared to claims made by these media themselves in the news sections as well as in the editorials. The newspaper sample includes two quality newspapers with national reach (centerleft, center-right), one tabloid, and one regional newspaper.

\section{The media's role in Europeanization of the public sphere}

Since the early 1990s, a significant strand of research has evolved that emphasizes the centrality of media in a potentially emerging European public sphere (Gerhards, 1993, 2000; Schlesinger, 1997; Schlesinger and Kevin, 2000; Kunelius and Sparks, 2001; Kevin, 2003; Trenz, 2002; Koopmans and Erbe, 2004). With respect to the possible development of a mass-mediated European public sphere, scholars have come to agree that the realization of a genuinely transnational mass media system maintaining the political functions of a democratic European public sphere, is rather unlikely ${ }^{2}$. Linguistic boundaries, cultural heterogeneity, and the fact that media systems are strongly focused on national mass audiences are crucial and perhaps insurmountable barriers to the formation of a unified European public sphere, which would be a replication at the European level of the structure we know from national media systems. Several scholars (e. g., Gerhards, 1993, 2000; Schlesinger and Kevin, 2000) have, therefore, come to argue that the potentially emerging European public sphere should be sought within the national public spheres of the various European countries. This perspective maintains that Europeanization "is for the most part dependent on the output of the national media" (Kevin, 2003: 52).

Empirical studies that investigate Europeanization in terms of the visibility of European issues ${ }^{3}$ in national media present rather sobering findings. Gerhards (2000: 294-295) and Eilders and Voltmer (2003:16) find that European issues comprise between six and seven percent, on average, of all issues in German quality press between the 1960s and the 1990s. This percentage remains largely stable over time and only increases marginally in the early 1990s. The low visibility of European issues also seems to hold for other types of media and other countries. Except for the periods of European summit meetings, a rather low coverage of EU related stories can be observed in television news in France, Germany, the Netherlands, and the United Kingdom. Only in Denmark the EU was more prominent in television news (Peter and de Vreese, $2003)^{4}$.

For this lack of visibility of European issues and actors in the media a number of reasons can be identified that stress the contradictory incentives underlying the political logic of the EU and the logic of national media organisations (Gerhards, 1992, 1993). It is argued that the Euro- 
pean decision-making process would not produce enough newsworthy messages and events on a regular basis, which comply with news values of the media. It is also emphasized that European actors are not dependent on public legitimization or support of the European citizenry, and, therefore, do not have any incentive to go public on a European level. This mechanism reduces the opportunities for the media to personalize European politics. Hence, the general argument is that European politics do not cater to the attention rules of the media, which undermines its public visibility ${ }^{5}$. In combination, the logics of both EU politics and media organizations seem to constitute mutually reinforcing factors that fuel a vicious circle, that continuously reproduces the visibility deficit of Europe in the media. ${ }^{6}$

In this line of reasoning it seems that the media are implicitly put on the spot for hindering the Europeanization of public communication. We argue that this position should be revisited, because no empirical evidence for the Euro-scepticism of the media can be identified if compared to other political actors. Our argument refers to the media as political actors in their own right (Page, 1996), in addition to their role as mediators of information from external sources. Thus, we see the media in public communication in a dual role of conveyors of external information and active participants in political discourse. On the one hand, they convey a constructed reality of messages created by external sources that is processed according to their selection rules and media formats. On the other hand, the media stand out as actors in their own right. In this role, they are acknowledged as actors in the public sphere that legitimately contribute to the political discourse by adding their own voice in specific formats such as commentary and editorials.

Reflecting on the dimensions in which the dual role of the media plays out in Europeanized public debate, Eilders and Voltmer (2004) discuss (1) agenda-setting and 'second level agenda-setting' (or framing); and (2) opinion formation which refers to presenting positions on issues and actors' evaluations. In their function as agenda-setters, the media select issues from external sources and present them as topics for public deliberation (Dearing and Rogers, 1996; Protess and McCombs, 1991). Within the recognized formats or commentary sections, they may not follow the rank order of issues by non-media actors and introduce their own saliencies on the issue agenda. The same duality applies to the socalled 'second-level agenda-setting' function (Ghanem, 1997; McCombs et al., 2000) or framing (Gamson, 1992), which refers to the contextualization of issues, namely the construction of a framework of interpretative meaning and opinion around an issue. Again, publicly visible frames can be rooted either in the communicative actions of external actors or stem from the interpretations of the media themselves. One can expect 
that these do not necessarily coincide. The media's own agenda may well emphasize European issues and frames while, at the same time, some political actors adhere to a predominantly national perspective.

The most genuine and specific media function refers to their active role in opinion formation. This function is institutionalized in commentaries, where the media enact their role as opinion makers. Eilders and Voltmer (2004) point out that the media in most national public spheres take stances according to a more or less stable commentary line. The commentary line contributes to the identification of a media outlet, and situates it within the spectrum of political cleavages. In many countries, however, European politics are not strongly linked to the traditional leftright spectrum, so that the national cleavages cannot be transferred to European politics. In this case, the media have more room to maneuver politically in as far as their opinion on European issues is concerned. In such circumstances, the media may choose to follow the opinion of the political elite, but they may also side with other interests such as civil society organizations, or speak in line with general public opinion. Another function that comes with the notion of media as political actors and which is institutionalized in the media format of commentaries, refers to their legitimate potential to evaluate and criticize other actors. Thus, the media may be favorable towards European integration and yet yield critical opinions on the performance of European or national actors.

\section{Conceptual framework for the study of media and political actors in public debate}

In our empirical study, we aim to compare the voice of the media with the voice of political actors and civil society actors with regard to the Europeanization of public debate in seven policy fields. Following our notion of Europeanization, we propose that the spatial reach and boundaries of public communication can be determined by investigating patterns of communicative flows and assessing the relative density of public communication within and between different political spaces (Koopmans and Erbe, 2004). The center of this communicative space is the German public sphere. The next level of communication refers to other national European public spaces, which comprise the European member states. The third level comprises the transnational, European political space, in which the European institutions and common policies are situated. The degree to which public spheres can be considered 'national', 'transnational', or 'European' depends on the density of communicative linkages within and between these spaces. The media - as well as other actors may engage in two basic forms of geo-political and spatial contextualiza- 
tion of their public communication: The pattern of vertical Europeanization consists of communicative linkages between the national and the European level. The pattern of horizontal Europeanization consists of communicative linkages between different EU-member states.

In order to assess the role of the media compared to other actors, we consider individual public claims by different collective actors ${ }^{7}$. Our units of analysis are individual acts of expression of public political opinion, which we label as claims. We define an instance of claim-making as a unit of strategic action in the public sphere that consists of the purposive and public articulation of political demands. An act of claim-making usually consists of the following elements: (a) a subject actor, or claimant, who makes a demand, proposal, appeal, or criticism; (b) an addressee, who is held responsible for implementing the claim, or is the target of criticism or support; (c) an object actor, whose interests are or would be positively (beneficiary) or negatively affected by the claim; the substantive content of the claim, stating (d) what is to be done (aim) and (e) why (frame). Claims are included regardless of their form (statement, decision, demonstration, court ruling, etc.) and regardless of the nature of the actor (media, governments, civil society actors etc.). Statements by the media are recorded if a journalist makes a claim in an explicit way in the news coverage or, as is more frequently the case, in commentaries and opinion pieces.

By taking instances of claim-making as the units of analysis, we are in a position to identify who speaks publicly to whom, in whose interest, and with reference to which issues and argumentative frames. Thus, we are able to measure in detail the interactive and argumentative structure of public communication and the linkages between the actors. Our data allow us to analyze the claim-making of detailed actor categories (e.g., German farmers or the European Parliament), but for the purpose of the following analysis the focus lies on three broad actor categories. Besides the media, we look at state and party actors, who can be regarded as the actors at the centre of the political system, and interest groups and civil society actors, who try to influence the system from the periphery.

Another significant feature of our study design is that we do not seek for a Europeanization of public communication on a very general level, gathering data across all possible political issues. Instead, we do not consider Europeanization to penetrate the national public spheres in all themes of public debate or all policy fields. Considering the large differences in the actual competencies of European institutions among different policy fields, it is relatively meaningless to compute a summary measure of the degree to which European institutions and policies are mentioned across all political issues. Instead, we take a political opportu- 
nity structure perspective (see Kriesi, Koopmans, Duyvendak, and Giugni, 1995; Koopmans, Statham, Giugni, and Passy, 2005), which leads us to expect patterns of claim-making that reflect the actual distribution of power between the European and the national level, as well as the distinction between the European decision-making process at a primarily intergovernmental level and decision-making at a primarily supranational level. In order to test this assumption, the study design includes seven issue fields. In addition to the meta-field of European integration, six substantive policy domains were selected systematically according to their level of formal Europeanization, reaching from fully integrated to merely coordinated domains: (1) monetary politics and (2) agriculture represent issue areas that are characterized by a high degree of EU involvement in national politics, which to an important extent entails supranational powers for EU institutions, (3) immigration and (4) militarytroopdeployment mark the policy areas in which we observe increasing EU competencies (or at least attempt to increase the EU's role), but where national decision making is still predominant and the EU political process is dominated by intergovernmental negotiations. Finally, (5) retirement and pensions, and (6) education are domains that have largely remained under the umbrella of national or regional decision-making, with a limited role for the EU.

\section{Data and methodology}

For the analysis of political claims made by media and political and civil society actors, we draw on the news coverage and editorials of four daily newspapers of different types that were selected to represent the national German print media landscape: A center-left (the Süddeutsche Zeitung) as well as a center-right quality newspaper (the Frankfurter Allgemeine Zeitung), a tabloid paper (the Bild-Zeitung), as well as a regional newspaper in a region with a specific regional identity (the East German Leipziger Volkszeitung). The data refer to the years 2000 to 2002.

To limit the coding of claims to manageable proportions, a sampling strategy was used regarding the newspaper sources. Because of the larger amount of potentially relevant articles, a more limited sample of news coverage was taken than merely of editorials. Regarding news coverage, we coded one issue per week of each of the two quality newspapers. For the year 2000, we also coded one issue every two weeks for the tabloid and regional newspapers. However, we did not use these data in the analysis as they would lead to an artificial overrepresentation of the year 2000, given the fact that our samples for 2001 and 2002 exclude these two newspapers. However, we did use the 2000 coverage data on the regional and tabloid papers to see if large qualitative differences existed 
in the types of issues and actors that were reported as compared to the coverage of the two quality papers. These differences turned out to be very small, suggesting that the distribution of coverage across issues and actors does not depend much on the newspaper chosen - this to some extent contradicts the differential attention given to certain actors and issues in these newspapers' editorials (see the results below) ${ }^{8}$. To further limit the amount of work, in half of the newspaper issues that were included in the news coverage sample for the years 2000 and 2002, we merely coded claims with a European dimension. This reduced sample of only Europeanized claims also applied to the news coverage sample for the whole year 2001. For the first part of our analysis (Tables 1-3), where we investigate degrees of Europeanization, we do not include the data for the year 2001, as well as those drawn from the 2000 and 2002 issues that were coded according to the reduced sample, since including them would have resulted in artificially inflated levels of Europeanized claims. However, in the second part of our analysis (Tables 4-5), where we look in detail at the positions taken, and the frames used in debates on European integration and European institutions, we can use our full data set as we focus on claims that have some kind of European dimension. In order to obtain sufficient cases to analyze the own voice of the media, a larger sample of editorials was taken. In this case, all four newspapers were coded for every second day of the year for the whole period 2000 to 2002 . The editorial data were coded for all sampled issues regardless of whether the content of the editorial referred to European dimensions or not. Nonetheless, for reasons of comparability with the news coverage, the editorial data for the year 2001 in Tables 1-3 was excluded. Altogether, the analysis draws on the news coverage articles from 312 newspaper issues (104 full sample issues and 208 with a reduced sample of only claims with a European dimension), and the editorials from 1,872 issues (1,248 issues excluding the year 2001).

The coding scheme of claims records the actor or claimant, the actors or institutions at which demands, criticism, or support is addressed, the object actors in whose interests (according to the claimant) the claim is made, and the content of the demand and the argumentative framing that supports it ${ }^{9}$. More importantly, to determine whether or not Europeanized claims are concerned, we coded the geographical or polity level at which the different actors and institutions that are mentioned in the claim (claimants, addressees, object actors) are situated (e. g., European or national), as well as, in the case of national or subnational actors, the country where they are based (e. g., Germany, France) ${ }^{10}$.

\section{The salience of European (dimensions of) issues}

Table 1 shows the issue agendas in the claims made by the four German newspapers, compared to the claims by state and party actors, on the 
one hand, and civil society actors, on the other. To correctly assess the role of the German media they are only compared to other German actors; any claims made by non-German actors are ignored.

Table 1. Issue agenda in claim-making of German news media and political actors, 2000 and 2002 (percent).

\begin{tabular}{|c|c|c|c|c|c|c|c|c|c|}
\hline & $\mathrm{SZ}$ & FAZ & LVZ & Bild & $\begin{array}{l}\text { Total } \\
\text { German } \\
\text { media } \\
\text { actors }^{15}\end{array}$ & $\begin{array}{l}\text { German } \\
\text { state and } \\
\text { party } \\
\text { actors }\end{array}$ & $\begin{array}{l}\text { German } \\
\text { civil } \\
\text { society } \\
\text { actors }\end{array}$ & $\begin{array}{l}\text { All } \\
\text { German } \\
\text { non- } \\
\text { media } \\
\text { actors }\end{array}$ & $\begin{array}{l}\text { All } \\
\text { German } \\
\text { actors }\end{array}$ \\
\hline $\begin{array}{l}\text { Monetary } \\
\text { politics }\end{array}$ & 23.7 & 20.7 & 16.9 & 39.4 & 22.2 & 6.5 & 31.2 & 13.2 & 17.2 \\
\hline Agriculture & 5.9 & 4.9 & 11.3 & 9.1 & 6.0 & 9.4 & 6.1 & 8.7 & 7.5 \\
\hline Immigration & 8.7 & 7.9 & 9.9 & 18.2 & 10.4 & 18.3 & 13.9 & 17.0 & 14.1 \\
\hline $\begin{array}{l}\text { Troop } \\
\text { deployment }\end{array}$ & 19.0 & 6.8 & 8.5 & 3.0 & 11.8 & 10.0 & 1.3 & 7.9 & 9.6 \\
\hline $\begin{array}{l}\text { Pensions/ } \\
\text { retirement }\end{array}$ & 9.9 & 10.5 & 15.5 & 18.2 & 11.8 & 22.4 & 20.3 & 21.7 & 17.3 \\
\hline Education & 4.3 & 15.0 & 9.9 & 0.0 & 9.2 & 17.3 & 20.3 & 18.1 & 14.1 \\
\hline $\begin{array}{l}\text { EU } \\
\text { integration }\end{array}$ & 28.5 & 34.2 & 28.2 & 12.1 & 28.5 & 16.0 & 6.9 & 13.5 & 20.2 \\
\hline Total & 100.0 & 100.0 & 100.0 & 100.0 & 100.0 & 100.0 & 100.0 & 100.0 & 100.0 \\
\hline $\mathrm{N}$ & 253 & 266 & 71 & 33 & 684 & 617 & 231 & 853 & 1,537 \\
\hline
\end{tabular}

Compared to non-media political actors, the German media pay considerably more attention to the issue of European integration. The two issue areas, however, that are most clearly institutionalized at a national level - education and pensions - are strongly underrepresented in the media claims. Attention for European integration is particularly low among German civil society actors. These actors are distinguished through a strong focus on monetary politics ${ }^{11}$. Between the four newspapers, some differences of emphasis exist regarding the attention that is given in their own claims to the six substantive issue fields. The Bild Zeitung makes a relatively large number of claims on monetary politics - particularly related to the introduction of the Euro - and on immigration. The regional Leipziger Volkszeitung's only distinguishing characteristic is the highest percentage of claims on agriculture, while the left-liberal SZ has a particularly strong focus on troop deployment, primarily related to the build-up to the US military intervention in Iraq. Notwithstanding these differences, the remarkable finding in this table is - in sharp contrast to what much of the literature on European public spheres would have us belief - that the German media (with the exception of the Bild Zeitung) have a rather strong interest in the issue of European integration when compared to non-media actors. 
Of course, Europeanized political communication should not necessarily change into debates on the meta-issue of European integration itself, but may occur emphasizing European dimensions when discussing the other six, more substantive policy issues. According to the predominant view on the role of the media in Europeanized political communication, the media are particularly prone to frame issues in a purely national perspective. Table 2 tests the validity of this argument for the vertical form of Europeanization, which consists of references to EU-level policies, actors, institutions, norms, and values.

Table 2. Percentage of claims by German actors with a vertical European frame of reference, by actor and issue field, 2000 and 2002 (percent) ${ }^{15}$.

\begin{tabular}{|c|c|c|c|c|c|c|c|c|c|}
\hline & $\mathrm{SZ}$ & FAZ & LVZ & Bild & $\begin{array}{l}\text { Total } \\
\text { German } \\
\text { media } \\
\text { actors }\end{array}$ & $\begin{array}{l}\text { German } \\
\text { state and } \\
\text { party } \\
\text { actors }\end{array}$ & $\begin{array}{l}\text { German } \\
\text { civil } \\
\text { society } \\
\text { actors }\end{array}$ & $\begin{array}{l}\text { All } \\
\text { German } \\
\text { non- } \\
\text { media } \\
\text { actors }\end{array}$ & $\begin{array}{l}\text { All } \\
\text { German } \\
\text { actors }\end{array}$ \\
\hline $\begin{array}{l}\text { Monetary } \\
\text { politics }\end{array}$ & 91.7 & 92.7 & 91.7 & 100.0 & 93.4 & 82.5 & 93.1 & 89.4 & 91.7 \\
\hline Agriculture & 80.0 & 76.9 & 75.0 & $(100.0)$ & 75.6 & 36.2 & 50.3 & 40.5 & 53.0 \\
\hline Immigration & 4.6 & 9.5 & 6.0 & 0.0 & 7.0 & 9. & 0.0 & 7.6 & 7.4 \\
\hline $\begin{array}{l}\text { Troop } \\
\text { deployment }\end{array}$ & $t^{10.4}$ & 27.8 & 50.0 & $(0.0)$ & 17.3 & 6.5 & $(0.0)$ & 6.0 & 12.1 \\
\hline $\begin{array}{l}\text { Pensions/ } \\
\text { retirement }\end{array}$ & 0.0 & 0.0 & 0.0 & 0.0 & 0.0 & 1.5 & 4.3 & 2.2 & 1.5 \\
\hline Education & 0.0 & 0.0 & 0.0 & - & 0.0 & 0.9 & 2.1 & 1.3 & 0.9 \\
\hline & 40.3 & 38.9 & 39.2 & 55.2 & 39.3 & 13.4 & 32.4 & 19.3 & 27.0 \\
\hline $\mathrm{N}$ & 181 & 175 & 51 & 29 & 489 & 518 & 215 & 738 & 1,227 \\
\hline
\end{tabular}

Note. Percentages based on less than five cases are in brackets.

The first thing to note about the results in this table is that the share of claims with vertical European references across all claimants strongly reflects the scope of EU competencies in each of these fields. Claims on monetary politics almost always refer to the European level $(92 \%)$, and the same is the case for a small majority $(53 \%)$ of agricultural claims. Much lower levels of Europeanized claims can be found for troop deployment (12\%) and immigration (7\%). The two issues in which the EU has merely a modest coordinating role - pensions $(2 \%)$ and education $(1 \%)$ - display the lowest levels of Europeanization in claim-making. This result complies with the political-opportunity-structure-explanation of patterns in the making of claims.

With regard to our comparison of media and other actors, the conclusion can be drawn that the press is somewhat more likely to frame issues with reference to the European level than other actors are. However, if 
differences between the issue fields are considered, it appears that this tendency is not present in all issue fields and does not apply equally to all of the newspapers. The largest difference between media and nonmedia claims is found in the field of troop deployment, where media claims $(17 \%)$ are almost three times more likely than the claims by nonmedia actors $(6 \%)$ to refer to European issue-dimensions. The exception is again the Bild Zeitung, but the low number of troop-deploymentclaims made by this paper $(\mathrm{n}=3)$ makes it difficult to draw any reliable conclusion. Also with respect to agricultural issues, it can be concluded that media claims $(76 \%)$ refer more often to European dimensions than non-media claims $(41 \%)$ do. As for immigration and monetary politics, the differences between media and non-media claimants are not striking. Pensions and education issues, finally, are the only themes for which European references are somewhat more frequent among non-media claims, but the percentages of claims in these fields that make such references are negligible for both categories of actors. The evidence does not unequivocally show that the media are more inclined to emphasize vertical European dimensions of issues; however, the results certainly do not suggest the received position that the media would be inclined to deemphasize the European dimension and to treat issues preferably in national terms.

Table 3. Percentage of claims by German actors with a horizontal European frame of reference, by actor and issue field, 2000 and 2002 (percent) ${ }^{15}$.

\begin{tabular}{|c|c|c|c|c|c|c|c|c|c|}
\hline & $\mathrm{SZ}$ & FAZ & LVZ & Bild & $\begin{array}{l}\text { Total } \\
\text { German } \\
\text { media } \\
\text { actors }\end{array}$ & $\begin{array}{l}\text { German } \\
\text { state and } \\
\text { party } \\
\text { actors }\end{array}$ & $\begin{array}{l}\text { German } \\
\text { civil } \\
\text { society } \\
\text { actors }\end{array}$ & $\begin{array}{l}\text { All } \\
\text { German } \\
\text { non- } \\
\text { media } \\
\text { actors }\end{array}$ & $\begin{array}{l}\text { All } \\
\text { German } \\
\text { actors }\end{array}$ \\
\hline $\begin{array}{l}\text { Monetary } \\
\text { politics }\end{array}$ & 20.0 & 23.6 & 25.0 & 0.0 & 20.4 & 17.5 & 4.2 & 8.9 & 15.5 \\
\hline Agriculture & 33.3 & 15.4 & 0.0 & (33.3) & 19.5 & 19.0 & 21.4 & 21.6 & 20.9 \\
\hline Immigration & 13.6 & 14.3 & 14.3 & 0.0 & 9.9 & 4.4 & 3.1 & 4.1 & 6.6 \\
\hline $\begin{array}{l}\text { Troop } \\
\text { deployment }\end{array}$ & 16.7 & 16.7 & 16.7 & $(0.0)$ & 16.1 & 11.3 & $(33.3)$ & 11.9 & 14.2 \\
\hline $\begin{array}{l}\text { Pensions/ } \\
\text { retirement }\end{array}$ & 0.0 & 3.5 & 0.0 & 0.0 & 2.5 & 0.7 & 0.0 & 0.5 & 1.1 \\
\hline Education & 18.2 & 5.0 & 0.0 & - & 6.4 & 0.0 & 0.0 & 0.0 & 1.8 \\
\hline $\begin{array}{l}\text { EU } \\
\text { integration }\end{array}$ & 59.7 & 56.0 & 60.0 & $(50.0)$ & 58.5 & 46.5 & 31.3 & 44.4 & 53.2 \\
\hline Total & 28.9 & 28.2 & 23.9 & 11.9 & 26.2 & 12.5 & 5.6 & 10.8 & 17.6 \\
\hline $\mathrm{N}$ & 253 & 266 & 71 & 33 & 684 & 617 & 231 & 853 & 1,763 \\
\hline
\end{tabular}

Note. Percentages based on less than five cases are in brackets. 
Table 3 gives an overview of the scope of horizontal Europeanization in cases where references are made by German actors to other EU member or candidate member states. Considering the differences between the seven issue fields for all actors, the results resemble those for vertical Europeanization. Comparing Tables 2 and 3 we see that the level of horizontal European communication is much lower than the level of vertical European communication for monetary politics and agriculture. In the other issue fields, vertical and horizontal Europeanization are more or less on the same - low - level. Interestingly enough, media claims $(26 \%)$ are over twice more likely to refer to other European countries than claims by non-media actors $(11 \%)$ are. Among the non-media actors, civil society actors $(6 \%)$ display lower levels of horizontally Europeanized claim-making than state and party actors (13\%); this indicates a reverse pattern from what we found for vertical aspects of Europeanization. The stronger degree of Europeanization of media claims now holds for six out of the seven issue fields. The only exception is agriculture, where we find similar levels of horizontal Europeanization in the claims of media and non-media actors (22\% for non-media and $20 \%$ for media claimants). The difference between media and non-media claimants is most pronounced in claims on European integration - 59\% of the media claims refer to other European countries against $44 \%$ of the non-media claims - and in monetary politics - references to other European countries can be found in $20 \%$ of the media claims against $9 \%$ of the non-media claims. Again, we have to make an exception for the Bild Zeitung; this newspaper refers half as much (12\%), in reference to the average of all newspapers (26\%), to other European countries. Nevertheless, even the level of Europeanization found in the Bild-Zeitung is comparable to the levels found for non-media actors.

The results, thus again, strongly disprove the perspectives that attribute the blame for a lack of Europeanization of public communication to a lack of attention of the media for Europe and to the media's alleged tendency to frame issues in purely national terms. The results so far indicate that the news media are more likely than other political actors to pay attention to European integration and to emphasize vertical and especially horizontal, transnational European aspects of issues. Not even the claims made in the editorials and journalist statements in the populist press are less Europeanized than the claims of non-media actors; although they are as expected more nationally focused than those of the other newspapers. The civil society actors are the only category that could be singled out based on the fact that their contributions to public communication on issues of European relevance lag behind institutional developments. This raises the question whether Europe's democratic and 
communication deficits perhaps do not so much concern a reluctance of the media to present issues from a European perspective, but the lack of a Europeanized civil society (see Koopmans, forthcoming).

\section{The evaluation of European integration and European institutions}

Even though the previous section showed that the mass media pay considerably more attention to European (dimensions of) issues than other actors do, this still leaves open the possibility that such attention for Europe is primarily negative. This, too, is a frequent assumption about the role of the media in the European integration process. In this view, if the media pay attention to Europe at all, they are said to tend to depict European policies and actors as conflicting with national interests, as inefficient, bureaucratic, and undemocratic, while national actors and policies are said to receive (at least in a relative sense) a more positive treatment. Table 4 tests the validity of this thesis. The first column shows the average position taken in relation to the European integration process by different actors. Position scores range from a score of -1.00 indicating a negative position with regard to European integration to +1.00 for a positive stance ${ }^{12}$. To interpret the data correctly, it is important to emphasize that what we measure here is an actor's general attitude towards the integration process. A positive attitude with regard to EU integration may well be combined with negative evaluations of particular EU actors or institutions, which is depicted in the second column.

Table 4 again shatters some common prejudices about the role of the media in discussions on European integration. Taking together all newspapers, we find that they on average take a more pro-European integration position $(+.38)$ than non-media actors $(+.25)$ do. Equally surprisingly, this holds also for the tabloid and regional papers (both .38). The result for the tabloid Bild Zeitung is perhaps the most remarkable and unexpected. We would, therefore, like to provide some qualitative examples drawn from the field of monetary politics to show what kind of claims are behind this result. Initially, Bild had been highly skeptical about giving up the Deutschmark. However, by the time of the actual introduction of the Euro coins and bills in January 2002, it had come to fully embrace the novelty. On January 2, 2002 Bild featured an editorial saying "The Euro is there and the Germans should form a friendship with their new currency. The new currency has something "eurotical"". Two months later, the paper defended the new currency against allegations that it had led to inflation: "Even if the German public thinks that with the Euro everything gets more expensive, this is wrong: Controllers have proven that the Euro is as stable as the old DM was" (Bild Zeitung, 9 March 2002). A month later, Bild no longer denied that prices had 
Table 4. Average position of German actors regarding European Integration and European institutions and actors 2000-2002 (Means).

\begin{tabular}{lcc}
\hline & $\begin{array}{l}\text { General position } \\
\text { regarding European } \\
\text { integration }\end{array}$ & $\begin{array}{l}\text { General position } \\
\text { regarding European } \\
\text { institutions and actors }\end{array}$ \\
\hline Green Party & .44 & -.11 \\
Süddeutsche Zeitung & .44 & -.11 \\
FDP (Liberal Democrats) & .43 & -.14 \\
Bild-Zeitung & .38 & -.38 \\
Leipziger Volkszeitung & .38 & -.18 \\
SPD (Social Democrats) & .38 & -.15 \\
All media actors & .38 & -.19 \\
Federal government & .37 & -.14 \\
Frankfurter Allgemeine Zeitung & .35 & -.24 \\
CDU (Christian Democrats) & .31 & -.48 \\
All state and party actors & .30 & -.20 \\
Bundesbank (Federal Bank) & .26 & .50 \\
All non-media actors & .25 & -.19 \\
Experts and professionals & .20 & -.13 \\
Bundestag (Federal Parliament) & .17 & -.21 \\
All civil society actors & .14 & -.17 \\
Employers & .14 & -.03 \\
Regional and local governments & .05 & -.61 \\
CSU (Bavarian Christian Democrats) & .02 & -.47 \\
Farmers & .00 & -.70 \\
Labour unions & -.14 & -.80 \\
\hline Overall average & .31 & -.19 \\
N & 1,358 & 674 \\
\hline Note. The scan ranges & & \\
\hline
\end{tabular}

Note. The scale ranges from +1 very positive to -1 very negative.

Position scores are listed only for actors or actor categories for which we had five or more cases on which to base on average score.

increased, but blamed shopkeepers, and neither the Euro nor the EU: "There has been a price increase because of the Euro, provoked by shops which have rounded up their prices. But it's not a general inflation" (Bild Zeitung, 20 April 2002). By June of the same year, Bild claimed to have always had the opinion that prices had risen and had embraced the slogan of the Euro as a 'Teuro' ('teuer' being the German word for expensive). But even then, Bild did not blame the currency itself or the EU, but 'unfair prices': "Because of many hidden price rises, the Euro is becoming a Teuro. It was the BILD-campaign against unfair prices that animated politicians to react" (Bild Zeitung, 1 June 2002). In other words, even in the middle of its populist campaign against price hikes, the Bild Zeitung did not choose to use the popular discontent about the 'Teuro' to launch an assault against the currency itself, let alone to demand a reintroduction of the Deutschmark. 
A further remarkable finding is that the positions of the four newspapers are very close, especially compared to the much broader range of variation among non-media actors. For instance, while the positions of political parties range from the euroskeptical CSU $(+.02)$ to the Europhile Greens $(+.44)$, the four newspapers are all situated at the Europhile end of the spectrum (from +.44 for the left-liberal SZ to +.31 for the conservative FAZ). In the German context, then, media communication on Europe seems a centripetal and pro-European, rather than a centrifugal force.

Some remarkable findings can also be found for non-media actors: Among the political parties, the Greens $(+.44)$, the centrist liberal and pro-business FDP $(+.43)$, and the social democratic SPD $(+.38)$ are clearly in the pro-European camp, while the Christian Democrat CDU $(+.31)$ takes a position at the centre of the ideological spectrum in Germany on the issue of European integration (see the +.31 overall average at the bottom of the table). The Bavarian CSU is the only (moderately) euroskeptical force $(+.02)$ in the German party spectrum (at least among the parties represented in the national parliament $)^{13}$. Not surprisingly, the national government, composed in the period under study of the SPD and the Greens, takes a position close to these parties (+.37). More remarkably, regional and local governments tend to be much less in favor of further European integration than the federal government $(+.05)$, a result which contradicts the assumption of an alliance between Europe and the regions united in common opposition against the nation-state that is popular in the academic literature ${ }^{14}$.

The results also provide additional evidence that the legitimacy problems that Europe faces are associated with its relation with the rest of civil society rather than with the news media. All civil society actors show below average levels of support for the integration process, and express much less support for European integration than the media, the national government, and most political parties do. European integration thus emerges as a project that is strongly supported by national political elites and by the media, but which is seen in a skeptical light by most civil society actors, and especially by those who have more to lose than to gain from exposure to the European market ${ }^{15}$.

As we have already indicated, support for the European integration process does not imply an uncritical attitude towards the way in which European institutions function at present. The second column in Table 4 shows that such a discrepancy between general support for European integration and specific support for European institutions and actors is indeed widespread. While on average the European integration process is moderately positively evaluated (on average +.31 ), European actors and institutions are evaluated negatively (on average -.19 ). However, 
Table 5.* Frames used in relation to European integration and European institutions, by claimant category, 2000-2002 (percent).

\begin{tabular}{|c|c|c|c|c|}
\hline & $\begin{array}{l}\text { State and } \\
\text { party actors }\end{array}$ & $\begin{array}{l}\text { Civil society } \\
\text { actors }\end{array}$ & Media & $\begin{array}{l}\text { All German } \\
\text { actors }\end{array}$ \\
\hline Principles, norms, values & 29.5 & 12.0 & 26.5 & 25.2 \\
\hline Community of values & 5.1 & 1.3 & 6.5 & 5.3 \\
\hline Modernisation & 1.9 & - & 2.3 & 1.8 \\
\hline Racism/xenophobia/nazism & - & 2.7 & 1.5 & 1.2 \\
\hline Social justice and equality & 1.9 & 1.3 & 2.3 & 2.0 \\
\hline International understanding & 1.3 & - & 1.5 & 1.2 \\
\hline Peace & 5.1 & 1.3 & 1.9 & 2.8 \\
\hline Unity & 3.2 & 1.3 & 1.5 & 2.0 \\
\hline Other & 11.0 & 3.8 & 9.0 & 8.9 \\
\hline $\begin{array}{l}\text { Constitutional and institutional } \\
\text { principles }\end{array}$ & 26.9 & 10.7 & 23.1 & 23.1 \\
\hline Democracy & 5.8 & 1.3 & 13.1 & 8.9 \\
\hline Equality among member states & 5.1 & 1.3 & 5.4 & 4.7 \\
\hline $\begin{array}{l}\text { Subsidiarity, federalism, central- } \\
\text { ization, separation of power }\end{array}$ & 8.3 & 2.7 & 1.5 & 3.9 \\
\hline Human rights & 1.3 & 1.3 & 1.5 & 1.4 \\
\hline Rule of law & 2.6 & 1.3 & 0.8 & 1.4 \\
\hline Other & 3.8 & 2.7 & 0.8 & 2.8 \\
\hline Good governance & 11.5 & 9.3 & 13.1 & 11.3 \\
\hline $\begin{array}{l}\text { Acceptance/legitimacy/credibility } \\
\text { in the eyes of the citizenry }\end{array}$ & 5.1 & 2.7 & 4.2 & 4.5 \\
\hline Transparency & - & 4.0 & 2.3 & 1.8 \\
\hline Efficiency & 4.5 & 1.3 & 2.3 & 2.8 \\
\hline Bureaucracy & 1.3 & 1.3 & 1.2 & 1.2 \\
\hline Other & 0.6 & - & 3.1 & 1.0 \\
\hline All identity frames & 67.9 & 32.0 & 62.7 & 59.8 \\
\hline General instrumental frames & 1.2 & 5.4 & 2.0 & 2.3 \\
\hline National interest & 0.6 & 2.7 & 1.2 & 1.2 \\
\hline $\begin{array}{l}\text { Freedom for citizens to work and } \\
\text { live elsewhere in the EU }\end{array}$ & 0.6 & 2.7 & 0.8 & 1.0 \\
\hline Political (dis)advantages & 8.9 & 5.3 & 6.2 & 6.9 \\
\hline Relations with USA & 1.9 & 1.3 & 2.7 & 2.2 \\
\hline Security & 3.8 & 2.7 & - & 1.6 \\
\hline Influence in international relations & 1.3 & 1.3 & 1.5 & 1.4 \\
\hline Other & 1.9 & - & 2.0 & 1.7 \\
\hline Economic (dis)advantages & 21.8 & 57.3 & 29.2 & 31.2 \\
\hline Economic stability & 4.5 & 9.3 & 12.3 & 9.3 \\
\hline Inflation and prices & 3.8 & 14.7 & 5.8 & 6.5 \\
\hline Economic growth & 3.2 & 12.0 & 2.7 & 4.3 \\
\hline Strength in global competition & 2.6 & 6.7 & 1.2 & 2.4 \\
\hline National economy and exports & 1.3 & 5.3 & 1.5 & 2.0 \\
\hline Consumer protection & 1.9 & - & 1.9 & 1.6 \\
\hline Other & 4.5 & 9.3 & 4.8 & 5.1 \\
\hline All instrumental frames & 32.1 & 68.0 & 37.3 & 40.4 \\
\hline Total & 100.0 & 100.0 & 100.0 & 100.0 \\
\hline $\mathrm{N}$ & 156 & 75 & 260 & 493 \\
\hline
\end{tabular}


this does not lead to the conclusion that a particularly high level of opposition to European institutions exists in Germany. These negative evaluations are not a specific characteristic of the public debate on European integration, but a general feature of German public debate in the media. If we compare the evaluations of EU institutions and actors to those of German national institutions and actors, we find that the negativism towards EU institutions and actors is much lower. The evaluation of German actors averages - .41 (not displayed in the table), whereas the evaluation of EU institutions and actors averages -.19 . For state and party actors, the average evaluations are -.34 (EU -.20$)$ for national actors, $-.48(\mathrm{EU}-.17)$ for civil society actors, and -.45 (EU $-.19)$ for media actors. Thus, all three actor categories view European actors and institutions less critically than national actors and institutions - once more a finding that contradicts the pessimistic tone that predominates in the literature on political communication in relation to European integration.

\section{Framing Europe}

In the final step of our analysis we compared the interpretations that are advanced to frame European integration, that is, the arguments that are used to back the position an actor takes on the political project of Europe. Here, the media are often held responsible for stimulating an instrumental and materialist view of European integration, and for deemphasizing the idealist dimension of Europe as a community of ideas, norms, and values. We investigate the empirical merits of this view by dividing the legitimizations that claimants give for their position on Europe's role in two broad categories. The first category, 'identity frames', refers to the normative issue of what Europe is or should be, and what it stands for or should stand for. The second type, 'instrumental frames' refers to the issue of Europe's functionality (or non-functionality) for other desired goods such as security or price stability. We further distinguish three subtypes of identity frames, referring respectively to principles, norms, and values (e. g., Europe as a promoter of international understanding or as an anti-racist community), constitutional and

\footnotetext{
*Note to Table 5. Although we additionally coded secondary and tertiary frames when present, the table lists only the primary frame of each claim. Separately listed are only those frames that have at least five mentions for all actors taken together. Note also that a frame may be used both negatively and positively with regard to the EU. We have also coded the direction in which a frame is linked to the EU. For the present analysis we ignore these differences, also because with our present data limitations the numbers of cases would quickly become too low for such more detailed analyses.
} 
institutional principles (e.g., democracy and human rights), and good governance arguments (e.g., the need for transparency and legitimacy). Instrumental frames are likewise divided in three subtypes, referring to general advantages or disadvantages of European integration (e. g., arguments of EU membership being in, or against the national interest), political advantages and disadvantages (e. g., together Europe has more influence in international politics), and economic advantages or disadvantages (e. g., economic growth).

The largest difference in Table 5 is between civil society actors on the one hand, and state and party as well as media actors, on the other. Civil society actors - which in this study are predominantly socio-economic groups and organizations - strongly emphasize the instrumental side of European integration ( $68 \%$ of all frames by civil society actors), particularly socio-economic advantages and disadvantages (57\%). Strength in global economic competition, economic stability, and economic growth were most often mentioned as advantages of European integration. Inflation and high prices, as well as adverse effects on the national economy (particularly linked to the introduction of the Euro) predominated among the disadvantages that were mentioned by civil society actors.

By contrast, both state and party, and media actors emphasize immaterial aspects of the European integration process. There are a few differences of emphasis, however, between the framing of German media and state and party actors. State and party actors are comparatively strongly preoccupied with constitutional and institutional arguments related to the future institutional structure of the EU, such as subsidiarity and federalism ( $8 \%$ of all state and party frames against only $2 \%$ of media frames), and they also more often bring up peace as a European value ( $5 \%$ among state and party frames, $2 \%$ among media frames), and security as an instrumental advantage of the EU ( $4 \%$ of state and party frames, none among media frames). The press, in contrast, mentions democracy more often as a core value of the European Union $(13 \%$ of media frames compared to $6 \%$ of state and party frames). The overall result, however, shows that the similarities between the framing used by the media and by state and party actors, and the contrast between these two categories and the civil society actors, are more striking than these relatively minor differences. The pattern for media frames holds for all four newspapers, although the regional LVZ mentions instrumental frames somewhat more often than the two national quality papers do. For the Bild Zeitung, we have too few cases $(n=3)$ to make any meaningful statement about frames. The Bild Zeitung not only has by far the lowest number of editorials of our four newspapers; only 14 per cent of the Bild editorials contain at least one frame, in comparison to 40 to 60 
percent in the other three newspapers. In other words, Bild editorials usually present opinions without much argument.

Summarizing, one can say that the media side with the political elites in terms of emphasizing constitutional principles and governance of the European Union, and the collective identities, norms, and values that Europe should stand for. In the end, there seems to be little truth in the common assumption that the German media stir up anti-European sentiments. Quite the contrary, the media converge with the political elites in strongly emphasizing a normative and largely idealist attitude towards the European integration process. The media criticism directed at European and national politicians refers to holding them accountable to these norms and values.

\section{Conclusion}

This study elaborates on existing research on the role of the media in the Europeanization of public spheres. The empirical results challenge the notion that the media are responsible for the resilience of largely nationally focused public spheres. Quite the contrary is the case, if we are to believe the findings on Germany for the years 2000-2002, which are presented in this article. The German press pays more attention and, in general, more favorable attention to the issue of European integration than other actors do (especially civil society actors). This also goes for European dimensions of other political issues. Moreover, much like the political elites, the media strongly emphasize Europe as a political community that rests on common ideals, norms, and values. Unlike other civil society organizations, they less often present instrumental and particularistic reasons for their support for, or opposition to, the European integration process. This study, therefore, does not yield evidence for the caricature of media as scapegoats for the lack of a European public sphere. Instead, we find that if the media speak with their own voice, they rather act as motors of Europeanization and so contribute to the opening up of spaces for transnational communication. By contrast, national political elites, and more strongly even non-media civil society actors are inclined to maintain the public debate within national boundaries.

Whether this is typical for the German media or represents a more general trend in Europe remains to be investigated by way of crossnational comparative analyses. At any rate, the results of this study show that lacking public attention and support for European integration cannot be attributed to general characteristics of the news media, such as the lack of 'news value' of European policies and actors, the media's catering to national audiences or the presumed national perspective that 
dominates among journalists and editors. It could be that in some other members states (e. g., the United Kingdom) the news media can be distinguished from other actors by paying less attention to European issues, being more critical towards the EU, and framing integration in instrumental and particularistic terms. However, if this were the case we would have to look for a context-sensitive explanation rather than general, decontextualized assumptions about how 'the media' work, which have thus far predominated in the debate on the Europeanization of public spheres. We think our analysis provides strong evidence against the common idea that the professional logic and news-gathering routines of the modern mass media stand in the way of the emergence of a Europeanized public sphere. Our results also provide strong indications that the lack of public attention and legitimacy for the EU may have other reasons than merely the nature of media coverage. The category of actors that is systematically least likely to address European issues, which is most likely to be critical of the integration process and of European institutions when it does address such issues, and which most strongly views the EU from an instrumental rather than from a normative point of view, are non-media civil society actors. If this reading of the findings is correct, Europe's problem is not inattentive or unfriendly media, but its distant and tenuous relations with its citizens and with their organized representatives.

It should be repeated that the findings draw on one national case for a limited period of time; they need to be completed by further investigations into the nature of public discourse within and across the European Union. Three trajectories seem valuable to pursue in future research. First, it is necessary to broaden the scope for comparative analyses of the role of the media in national public spheres to test the hypotheses regarding the context sensitive role of the media and other actors in various European member states (e. g., Pfetsch, 2005).

Second, an encompassing picture about transnational public communication in and about Europe would require including more national media than newspapers. Regarding the political functions of public communication, we see a division of labor between the various types and formats of mass media. If we look for political discourse and the exchange for arguments in political debate, we need to focus especially on the quality press, which in most countries plays a significant role as media opinion leader for political agenda building. When the claims analysis method was applied to television newscasts in Germany (Schlecht, 2002), it was found that news stories contain much less substantial arguing than press articles and editorials do. Thus, it was concluded that television is a secondary medium if we are to understand the transnational dimensions of political discourse across Europe. However, 
if one is to identify the daily, event-driven hoops of European politics which eventually may result in some sort of 'banal Europeanism' on the citizen's level, television news analysis should be the preferred choice. Yet another medium that merits investigation is the Internet, which can provide new opportunities for Europeanized political communication to circumvent the selection gates of the traditional media (see Koopmans and Zimmermann, 2003).

Third and finally, since the emergence of European public spheres relates to a long term social and political process, which gains its deeper meaning with respect to the political future of the EU, it would be highly important to add a diachronic perspective to the observation of transnational aspects of public communication. The current analysis only covers three recent years, but we hope it will serve as a point of reference and comparison for future longitudinal analyses of the role of the media in Europeanized political communication.

\section{Notes}

1. The project is coordinated by Ruud Koopmans, Free University Amsterdam. Project partners are Paul Statham, University of Leeds; Donatella della Porta, European University Institute; Hanspeter Kriesi, University of Zurich; Jos de Beus, Universiteit Amsterdam; Juan Diez Medrano, University of Barcelona, Virginie Giraudon, CRAPS Lille and Barbara Pfetsch, University of Hohenheim; for information see http://europub.wz-berlin.de.

2. If supranational media are to be detected, they are confined to a limited audience of political and business elites, who communicate in English, or are non-political media specialized in sports and music (Kevin, 2003: 38-41).

3. The studies discussed here draw on rather simple measures, such as the percentage of European issues and actors in news coverage (e. g., Peter and de Vreese, 2003; Kevin, 2003). Often also, conclusions are drawn from secondary analyses of data that were gathered for other purposes (e.g., Gerhards, 2000; Eilders and Voltmer, 2004).

4. The Danish level of television coverage of EU affairs amounts to nineteen percent of all news stories in routine periods, and twenty-five percent in summit periods.

5. This argument is corroborated by the findings of Peter and de Vreese (2003), who show that more spectacular European events such as summit meetings do receive slightly higher levels of coverage, and that public mobilizations or referendums about European issues create a significant visibility of EU politics. This visibility, however, helps national actors to gain prominence on European issues.

6. It has further been argued that national media organizations devote rather limited resources to their news infrastructure in Brussels, and information flows in Brussels and the networks of EU-correspondents tend to be organized along national lines. However, Meyer (1999) shows that the resources of media in Brussels have considerably increased, and that transnational networks of journalists have emerged.

7. See Koopmans and Statham (1999) for a further discussion of this methodology.

8. Contrary to these small qualitative differences, there were large differences in the quantity of coverage. The two quality papers reported many more relevant claims 
than the regional paper, which in turn was more inclusive than the very sparse coverage of the tabloid.

9. The coding manuals for the coding of claims in news coverage and in editorials are available online at http://europub.wz-berlin.de. These manuals contain full details on the sampling, the identification rules for claims, and the coding of individual variables.

10. To give the reader an idea of how this coding works, consider the following example of a claim in the field of troop deployment: "Foreign Minister Joschka Fischer criticized Britain and Spain's support for the USA's military campaign against Iraq, saying that this had undermined the search for a common European position on the issue". The claimant is Fischer, whose scope is coded as national, Germany; Britain and Spain are the addressees (with negative evaluation), the USA and Iraq are the object actors. Although these are all national actors, the issue is framed by Fischer in a European context. Thus, the issue scope in this case would be 'European'.

11. This is linked to a predominance of socio-economic actors among the civil society actors in our data: unions, employers, professional groups, and economists and financial experts together make up about sixty percent of the civil society actors.

12. These scores were calculated as averages across all claims made by a particular actor or category of actors. An individual claim was given a score of +1 if it was in favor of extending the competencies or resources of the EU in a certain issue field (or against reductions in these competencies), a score of -1 if it argued for a reduction in EU competencies or resources (or against an extension), and a score of 0 if it was neutral or ambivalent regarding extending or reducing EU competencies or resources (e. g., when a claim argued for a shift of competencies from one EU institution to another).

13. The only party represented in the national parliament that is not included in the table is the post-communist PDS. It has a centrist position score $(+.33)$; we did not include this score in the table as it is only based on three cases.

14. Closer inspection of the data shows that the low score for regional and local governments is not caused by the party composition of governments at this level, because regional SPD-led governments also tended to be more critical toward the European integration process than the national government.

15. See Koopmans (forthcoming) for evidence that confirms these results for all seven countries of our study.

\section{References}

Dearing, J. W. and Rogers, E. M. (1996). Agenda-setting. Communication concepts 6. London: Sage.

Eder, K. and Trenz, H. J. (2000). The making of a European public space: An inquiry into relating supranational politics and transnational spaces of communication. The case of justice and home affairs. Paper presented at the Linking EU and National Governance Conference, Mannheim, 1-3 June 2000.

Eilders, C. and Voltmer, K. (2004). Zwischen Marginalisierung und Konsens: Europäische Öffentlichkeit in Deutschland. In C. Eilders, F. Neidhardt, and B. Pfetsch (Eds.), Die Stimme der Medien. Pressekommentare und politische Öffentlichkeit in der Bundesrepublik (pp. 358-385). Wiesbaden: VS.

Gamson, W. A. (1992). Talking politics. Cambridge: Cambridge University Press.

Gerhards, J. (1992). Europäische Öffentlichkeit durch Massenmedien? In B. Schäfers (Ed.), Lebensverhältnisse und soziale Konflikte im neuen Europa: Verhandlungen des 26. Deutschen Soziologentages 1992 (pp. 558-567). Frankfurt a. Main: Campus. 
Gerhards, J. (1993). Westeuropäische Integration und die Schwierigkeiten der Entstehung einer europäischen Öffentlichkeit. Zeitschrift für Soziologie, 22(96), 96-110.

Gerhards, J. (2000). Europäisierung von Ökonomie und Politik und die Trägheit der Entstehung einer europäischen Öffentlichkeit. In M. Bach (Ed.), Die Europäisierung nationaler Gesellschaften. Sonderheft der Kölner Zeitschrift für Soziologie und Sozialpsychologie (pp. 277-305). Opladen: Westdeutscher Verlag.

Ghanem, S. (1997). Filling the tapestry: The second-level of agenda-setting. In M. McCombs, D. L. Shaw, and D. Weaver (Eds.), Communication and democracy: Exploring the intellectual frontiers in agenda-setting theory (pp. 3-14). Mahwah, NJ: Lawrence Erlbaum.

Kevin, D. (2003). Europe in the media: A comparison of reporting, representation and rhetoric in national media systems in Europe. Mahwah, NJ: Lawrence Earlbaum.

Koopmans, R. (forthcoming). Who inhabits the European public sphere? Winners and losers, supporters and opponents in Europeanised political debates. European Journal of Political Research.

Koopmans, R. and Erbe, J. (2004). Towards a European public sphere? Vertical and horizontal dimensions of Europeanised political communication. Innovation, 17, 97-118.

Koopmans, R. and Statham, P. (1999). Political claims analysis: Integrating protest event and public discourse approaches. Mobilization, 4, 203-222.

Koopmans, R., Statham, R., Giugni, M., and Passy, F. (2005). Contested citizenship. Immigration and cultural diversity in Europe. Minneapolis, MN: University of Minnesota Press.

Koopmans, R. and Zimmermann, A. (2003). Internet: A new potential for European political communication? Paper presented at the Conference Europeanisation of public spheres? Political mobilisation, public communication, and the European Union, Science Center Berlin, 20-22 June 2003.

Kriesi, H., Koopmans, R., Duyvendak, J. W., and Giugni, M. (1995). New social movements in western Europe: A comparative analysis. Minneapolis, $\mathrm{MN}$ : University of Minnesota Press.

Kunelius, R. and Sparks, C. (2001). Problems with a European public sphere: An introduction. Javnost, 8 (1), 5-20.

McCombs, M., Lopez-Escobar, E., and Llamas, J. P. (2000). Setting the agenda of attributes in the 1996 Spanish general election. Journal of Communication, 50, $77-92$.

Meyer, C. (1999). Political legitimacy and the invisibility of politics: Exploring the European Union's communication deficit. Journal of Common Market Studies, 37(4), 617-639.

Neidhardt, F., Koopmans, R., and Pfetsch, B. (2000). Konstitutions-bedingungen politischer Öffentlichkeit: Der Fall Europa. WZB-Jahrbuch (pp. 263-293). Berlin: Wissenschaftszentrum Berlin für Sozialforschung.

Page, B. (1996). The mass media as political actors. Political Science and Politics, 29(1), 20-25.

Peter, J. and Vreese, C. H. de (2003). In search of Europe: The European Union in national television news. Paper presented at the 53rd Annual Meeting of the International Communication Association, San Diego, CA.

Pfetsch, B. (2005). Media opinion in European public debate: An empirical study of newspaper editorials in seven countries. Paper presented at the 55th Annual Meeting of the International Communication Association, New York.

Protess, D. L. and McCombs, M. (Eds.). (1991). Agenda setting. Readings on media, public opinion, and policymaking. Hillsdale, NJ: Lawrence Erlbaum. 


\section{8}

Ruud Koopmans and Barbara Pfetsch

Schlecht, T. (2002). Europa in den deutschen Fernsehnachrichten. Eine Analyse des Nachrichtenmagazins Tagesthemen. Master's Thesis, Institut für Publizistik und Kommunikationswissenschaft, Free University Berlin, Berlin

Schlesinger, P. (1997). From cultural defence to political culture: Media, politics and collective identity in the European Union. Media, Culture and Society, 19(3), 369-391.

Schlesinger, P. and Kevin, D. (2000). Can the European Union become a sphere of publics? In O. E. Eriksen and J. E. Fossum (Eds.), Democracy in the European Union: Integration through deliberation? (pp. 206-229). London: Routledge.

Trenz, H. J. (2002). Zur Konstitution Politischer Öffentlichkeit in der EU. Zivilgesellschaftliche Subpolitik oder Schaupolitische Inszenierung. Baden-Baden: Nomos. 